Papers and Proceedings of the Royal Society of Tasmania, Volume 118, 1984

(ms. received $17 . \mathrm{vi} .1983$ )

\title{
A YOUNG STRAP-TOOTHED WHALE IN TASMANIAN WATERS
}

by E.R. Guiler

Sandy Bay, Tasmania

(with two tables)

ABSTRACT

GUILER, E.R., 1984 (31 viii): A young strap-toothed whale in Tasmanian waters. Pap. Proc. R. Soc. Tasm., 118: 65-68. https://doi.org/10.26749/rstpp.118.65 ISSN 0080-4703. 8 Tiersen Place, Sandy Bay, Tasmania, Australia.

The stranding of a young Strap-toothed whale is the first breeding record of this species in Australia. The species is present in Australian waters in summer probably associated with calving and the early growth of young. Measurements are given of the skull of the young whale.

\section{INTRODUCTION}

The Strap-toothed whale MesopZodon Zayardii (Gray, 1865), family Ziphiidae, has a circumpolar distribution being found in New Zealand (Gaskin 1972), South Africa (Gray 1865), Australia (Dixon 1980) and South America (Bruyns 1971). In spite of this wide distribution little is known of its biology, although specimens have been examined at more than 50 strandings, most of these being in New Zealand and Tasmania.

\section{THE EVENT}

On 20 January 1983 two whales were reported stranded in northeastern Tasmania. The whales were of different sizes and the larger animal had been dead for a few days and was rolling about in the surf at Little Musselroe Bay ( 1 at. $40^{\circ} 45^{\prime} \mathrm{S}, 1$ ong. $\left.148^{\circ} 05^{\prime} \mathrm{E}\right)$. The second whale was smaller and stranded at nearby Lanoma Point (1at. $40^{\circ} 44^{\prime} \mathrm{S}, 1 \mathrm{ong} .147^{\circ} 58^{\prime} \mathrm{E}$ ) and was in a more advanced state of decay than the other specimen. The skull of each whale was recovered by $\mathrm{Mr}$ P. Allbrook.

Both whales were Mesoplodon Zayardii (Gray). Some doubt exists about the sex of the Musselroe specimen which photographs show to have been large (about $6 \mathrm{~m} \mathrm{long}$ ), and clearly an adult. The original stranding report from N.P.W.S. Ranger Le Fevre stated that one of the residents in the area remembered seeing the animal's penis. The mesorostral groove was ossified for one-half of its length but doubt exists about the use of this feature in determining sex, Nishiwaki \& Kamiya (1958) expressing reservations regarding its validity. McCann (1965) concluded that the ossification of the groove was an indication of age. However, the teeth of the whale were not of the elongated, blunt form of the male (Watson 1981) but were small, pointed and although each tooth had penetrated the side of each mandible to the extent of 2-3 $\mathrm{mm}$ it had not appeared above the surface of the gums. From this, I conclude that the specimen probably was female.

The smaller whale was estimated by Mr Allbrook to be about $2.5 \mathrm{~m}$ in length. The birth length of these whales is about $2.2 \mathrm{~m}$ (Watson 1981) and this size, combined with the characters of the skull identify the whale as a juvenile M. Zayardii. The teeth, although not erupted through the gums, were of the male form. The sutures of the skull were ossified with the exception of the premaxillary which was poorly ossified along its posterior and postero-lateral surfaces.

As this is the only skull reported from a juvenile of this species full measurements are given, using the criteria of Moore (1963) (table 1). Dimensions are also given of the adult skull since it is an unusually large specimen (Warneke 1963). 
TABLE 1

THE SKULL MEASUREMENTS OF TWO MESOPLODON LAYARDII FROM TASMANIA. Measurements (mm) and numbers follow the system of Moore (1963).

1 Greatest length of skull

Juvenile Adult

2 Greatest length of rostrum from tip to line connecting apices of antorbital notches

3 Tip of rostrum to posterior margin of pterygoid nearest midsagittal plane

4 Tip of rostrum to posterior wing of pterygoid

5 Tip of rostrum to most anterior extension of pterygoid

6 Tip of rostrum to most posterior extension of maxillaries between the pterygoids

7 Tip of rostrum to most posterior extension of maxillary plate

8 Tip of rostrum to anterior margin of superior nares

9 Tip of rostrum to most anterior point on maxillary crest

10 Tip of rostrum to most posterior extension of temporal fossa

11 Tip of rostrum to most posterior extension of lateral tip of premaxillary crest

12 Tip of rostrum to most anterior extension of pterygoid sinus

13 Greatest length of temporal fossa

14 Greatest length of orbit

15 Greatest length of right nasal on vertex of skul1

16 Length of nasal suture

17 Greatest breadth of skull across posterior orbital process of frontals

18 Greatest breadth of skull across zygomatic process of squamosals

19 Greatest breadth of skull across centres of orbits

20 Least breadth of skull across posterior margins of temporal fossae

21 Greatest lateral spread of occipital condyles

22 Greatest width of wider occipital condyle

23 Greatest length of longer occipital condyle

24 Greatest width of foramen magnum

25 Greatest lateral spread of exoccipital bones

26 Greatest lateral spread of nasal bones

27 Greatest distance between premaxillary crests

28 Greatest extension of right premaxilla posterior to right nasal

29 Greatest spread of premaxillary crests

30 Narrowest spread of smooth part of premaxillae beside nares

31 Greatest spread of premaxillae anterior to no.30

32 Greatest spread of premaxillae at middle of rostrum

33 Greatest width of rostrum at apices of antorbital notches

34 Greatest width of rostrum at apices of preminential notches

35 Greatest width of rostrum at midlength of rostrum

36 Greatest depth of rostrum at midlength of rostrum

37 Greatest transverse width of superior nares

38 Inside width of inferior nares at apices of pterygoid notch

40 Greatest width of temporal fossa perpendicular to long axis

41 Least distance between main or anterior maxillary foramina

42 Least distance between premaxillary foramina

43 Posteromesial margin of left maxillary foramen to apex of left antorbital tubercle

44 Greatest length of vomer on surface of palate

47 Centre of right orbit to nearest margin of superior nares

48 Centre of left orbit to nearest margin of superior nares

49 Apex of pterygoid notch to anterior edge of pterygoid sinus

50 Greatest width of pterygoid sinus perpendicular to long axis

690

1090

410

495

530

330

870

880

650

$400 \quad 680$

$610 \quad 990$

$470 \quad 835$

$480 \quad 840$

$600 \quad 930$

558

490

96

85

40

25

275

285

280

215

105 


\section{E.R. Guiler}

\section{DISCUSSION}

The occurrence of a juvenile M. Layardii constitutes the first breeding record for this species in Australian waters. Although not an uncommon species, some 28 individual strandings have been recorded from Australia by Dixon (1980) and 19 from New Zealand (Gaskin 1972), little is known of its biology, particularly its reproduction. Gaskin (1972) reported that two females with foetuses were found in New Zealand in winter, whilst Bruyns (1971) recorded a female stranded in September, having just given birth to a calf.

The time of stranding of this specimen together with its size and the degree of ossification of its cranial bones would support the suggestion of a spring-early summer calving.

The largest number of strandings takes place in the summer months in Australia (table 2). The table suggests that whales are absent from Australian coastal waters from August through November and only return in December. The rapidity of the increase in strandings in January suggests that there is a movement either into Australian waters at this time or alternatively that the whales move into the coastal regions where strandings are more likely to occur. The information is not incompatible with the proposition that calving takes place in or adjacent to coastal waters in late spring or early summer gaining some protection for the young from sharks while the female seeks food from the squid shoals which are in coastal waters at that time. The whales then gradually move away with the onset of autumn.

TABLE 2

MESOPLODON LAYARDII: AUSTRALIAN STRANDING RECORDS BY MONTH. Based on Dixon (1980) and McManus et al. (1984). Excludes one undated winter record of Dixon.

Jan Feb Mar Apr May Jun Jul Aug Sep Oct Nov Dec

$\begin{array}{llllllllllll}12 & 8 & 2 & 2 & 2 & 1 & 3 & 0 & 0 & 0 & 0 & 1\end{array}$

Some speculation exists as to whether this was a mother and calf stranding, some residents claiming to have seen two whales keeping company in the area before the stranding. The different stages of decay of the two whales suggest that they died at different times. If the adult was the mother of the calf and she died first then it would be expected that the calf would soon die as it would certainly have been nursing.

The juvenile skull has been deposited in the Tasmanian Museum, and the adult skull is held by the author.

\section{ACKNOWLEDGEMENTS}

I am grateful to $\mathrm{Mr} \mathrm{H}$. Wapstra, National Parks and Wildlife Service who was responsible for organizing the efforts to obtain these skulls and make them available to me. Ranger R. Le Fevre of the same Service was instrumental in the collection of the skulls from the sites. Mr P. Allbrook is specially thanked for his efforts in recovering the heads, without which they would have been lost.

\section{REFERENCES}

Bruyns, W.F.J.M., 1971: FIELD GUIDE TO THE WHALES AND DOLPHINS. Amsterdam.

Dixon, J.M., 1980: A recent stranding of the Strap-toothed Whale, Mesoplodon layardii (Gray) (Ziphiidae) from Victoria, and a review of Australian records for the species. Vict. Nat., $97(1): 34-41$.

Gaskin, D.E., 1972: WHALES, DOLPHINS AND SEALS. Heinemann, Auckland.

Gray, J.E., 1865: Ziphius layardi from the Cape of Good Hope. Proc. zool. Soc. Lond., $1865: 358$.

McCann, C., 1965: The mesorostral groove in Ziphiidae, with special reference to its closure by ossification in Mesoplodon - Cetacea. Rec. Dom. Mus., 5(12): 83-88. 


\section{A Young Strap-toothed Whale in Tasmanian Waters}

McManus, T.J., Wapstra, J.E., Guiler, E.R. Munday, B.L. \& Obendorf, D.L., 1984: Cetacean strandings in Tasmania from February, 1978 to June, 1983. Pap. Proc. Roy. Soc. Tasm., 118: $117-135$

Moore, J.C., 1963: Recognizing certain species of beaked whales of the Pacific Ocean. Amer. Midl. Nat., 70(2): 396-428.

Nishiwaki, M. \& Kamiya, T., 1958: A beaked whale, Mesoplodon, stranded at Oiso Beach, Japan. Sci. Rept Whales Res. Inst. Tokyo, 13: 53-84.

Warneke, R.M., 1963: A record of the beaked whale (Mesoplodon Layardi) in Victorian waters. Vict. Nat., $80(3): 68-73$.

Watson, L., 1981: SEA GUIDE TO WHALES OF THE WORLD. Hutchinson, London. 